\title{
Galium verum aqueous extract strongly inhibits the motility of head and neck cancer cell lines and protects mucosal keratinocytes against toxic DNA damage
}

\author{
MARIANNE SCHMIDT, CHRISTINE POLEDNIK, JEANETTE ROLLER and RUDOLF HAGEN \\ Department of Otorhinolaryngology, University of Wuerzburg, D-97080 Wuerzburg, Germany
}

Received April 22, 2014; Accepted May 28, 2014

DOI: $10.3892 /$ or.2014.3316

\begin{abstract}
Galium verum, also known as Lady's Bedstraw, is an herbaceous plant native to Europe and Asia, and has been used in traditional medicine as an anticancer medicine applied in most cases as a decoction. The influence of a Galium verum decoction on the head and neck cancer cell lines HLaC78 and FADU was analyzed and proved to be toxic in high doses on both cell lines. Cytotoxicity appeared to be influenced by expression of p-glycoprotein (MDR-1) in the carcinoma cell lines. Mucosal keratinocytes, although void of MDR-1 expression, showed only low sensitivity against high Galium concentrations. Sublethal doses of Galium extract acted as strong inhibitors of motility, as shown by a spheroid-based invasion analysis on Matrigelcoated surfaces. Inhibition of invasion was significantly more pronounced in the invasive HLaC78 cell line. mRNA expression analysis of matrix metalloproteinases MMP-2 and MMP-9 and their inhibitors TIMP-1/-2 revealed significant TIMP-1 upregulation after an 8-h Galium exposition in FADU cells. Gelatinolytic activity, however, was not influenced by Galium extract in HLaC78, in the FADU cells MMP-2/-9 activity was slightly increased after incubation with Galium extract. In primary mucosal keratinocytes, Galium decoction protected DNA against benz $[a]$ pyrene, one of the most DNA toxic agents in cigarette smoke. In conclusion Galium extract may be useful as a preventive and/or a concomitant therapeutic approach in head and neck cancer.
\end{abstract}

\section{Introduction}

According to an analysis in 2009 of over 3,000 cases of primary head and neck tumours in Germany, the outcome of this disease did not significantly improve from 1995 to 2006, despite new treatment strategies. Particularly the 5-year overall survival rate for carcinomas of hypopharyngeal origin is extremely low at $27.2 \%$ (1). Moreover, in advanced laryn-

Correspondence to: Dr Marianne Schmidt, Department of Otorhinolaryngology, University of Wuerzburg, Josef-SchneiderStrasse 11, D-97080 Wuerzburg, Germany

E-mail: schmidt_m2@klinik.uni-wuerzburg.de

Key words: Galium verum, cancer, carcinoma, head and neck, paclitaxel, herbal drug, metastasis, in vitro, HNSCC geal and hypopharyngeal cancer, the functional and cosmetic deformations produced by surgery can be very disabling for patients. Chemoradiation is meanwhile commonly used for advanced head and neck cancer in order to preserve laryngeal and/or pharyngeal structures. Paclitaxel is one of the agents used with high response rates; however, it failed to reach local-regional tumour control in $12 \%$ of patients according to a previously published study (2).

Galium verum, also known as Lady's Bedstraw, is an herbaceous perennial plant of the family Rubiaceae, native to Europe and Asia. Studies on Galium verum predominantly originate from the Asian continent, where traditional medicine is more frequently embedded in culture. However, in industrial nations traditional phytomedicine has gained more and more attention, especially with respect to alternative treatments of cancer.

The cut and dried aerial parts of Galium verum have been used for exogenous treatment of psoriasis or delayed wound healing or as a tea with diuretic effect for the cure of pyelitis or cystitis (3). Today the use of Galium verum is considered to be obsolete, although it is still mentioned in popular non-scientific publications and in internet platforms as an anticancer medicine.

On the scientific level, a variety of bioactive substances have been identified in Galium verum plants such as iridoid glycosides (4-6), flavanoids $(5,7,8)$, anthraquinones (9) and chlorogenic acid (10). Galium species are known to have antioxidant [Galium verum (11)], antimicrobial/antifungal [Galium tricornutum (12)], antifeedant [Galium aparine (13)] and insecticidal [Galium melantherum (14)] properties.

According to a detailed survey by Hartwell (15) Galium verum has been traditionally used in Europe and Northern America for the treatment of cancerous ulcers or breast cancer.

Amirghofran et al (16) showed a cytotoxic effect of Galium mite methanolic extracts on K561 and Jurkat cells. Zhao et al isolated diosmetin from Galium verum plants and showed protective effects on the thymus of U14-bearing mice (17).

In the present study, we tested the influence of a Galium verum 'tea' (decoction) on the growth and behaviour of head and neck cancer cell lines and primary mucosal keratinocytes.

\section{Materials and methods}

Cell lines and cell culture. The cell line FADU originating from a hypopharyngeal carcinoma was grown in RPMI-1640 
medium (Seromed, Munich, Germany), supplemented with $10 \%$ fetal calf serum (FCS). The HLaC78 cell line originated from a larynx carcinoma (18) and was maintained similar to FADU cells in RPMI-1640 medium. Mucosal keratinocytes were prepared from tonsillar tissue according to standard protocols (19). In brief, the mucosa was cut into small pieces and incubated overnight with $0.2 \%$ dispase (Sigma-Aldrich, Steinheim, Germany) in Dulbecco's modified Eagle's medium (DMEM; Seromed). The epithelium was separated with sterile forceps and digested with $0.1 \%$ trypsin (Seromed) for $20 \mathrm{~min}$ at $37^{\circ} \mathrm{C}$. Residual trypsin was inactivated by addition of FCS. Mucosal keratinocytes were collected by centrifugation and cultured in defined keratinocyte serum-free medium (Keratinocyte-SFM; Invitrogen, Karlsruhe, Germany).

Galium verum decoction. Dried and cut Galium verum L. leaves (Herba galii lutei) were kindly provided by Dr Ivo Pischel, PhytoLab GmbH \& Co. KG (Vestenbergsgreuth, Germany). Tea was prepared as follows: $100 \mathrm{ml}$ boiling water was poured over $15 \mathrm{~g}$ of dried and powdered Galium leaves. After cooling, the supernatant was cleared by centrifugation and sterile filtration. Aliquots were frozen at $-80^{\circ} \mathrm{C}$. One batch of frozen Galium extract was used for all experiments. Identification of the extract ingredients is presented elsewhere (20).

Real-time PCR. To measure gene expression rates, real-time TaqMan ${ }^{\circledR}$ PCR (Applied Biosystems) was performed. RNA was isolated from cell lines and primary cells with the RNeasy kit (Qiagen, Hilden, Germany) according to the manufacturer's instructions. The High Capacity RNA-to-cDNA Master Mix (Applied Biosystems, Darmstadt, Germany) was used for cDNA reverse transcription. Real-time PCR was performed in triplicates on a real-time PCR cycler (Applied Biosystems) using the TaqMan gene expression assays for MDR-1, MMP-9/MMP-2 and TIMP-1/-2. Relative quantification was calculated according to the $2^{-\Delta \Delta \mathrm{CT}}$ method (21). Expression values were normalised to the expression of GAPDH as an endogenous control which proved to be expressed most stably throughout the cell lines.

Cell viability and proliferation assay. Cells were seeded at 5,000 cells/well in 96-well plates. Cells were treated with increasing concentrations of Galium verum aqueous extract (50 and $100 \mu \mathrm{l} / \mathrm{ml}$ ) for $48 \mathrm{~h}$. Controls were kept in medium supplemented with $100 \mu \mathrm{l} / \mathrm{ml}$ water. Cell proliferation was measured after $48 \mathrm{~h}$ by replacing the culture medium with medium containing $1 \mathrm{mg} / \mathrm{ml}$ MTT. After a 4-h incubation, MTT staining solution was replaced by isopropanol, and the cells were incubated at $37^{\circ} \mathrm{C}$ for $45 \mathrm{~min}$. The colour conversion of MTT to a blue formazan dye was measured with an ELISA reader at a wavelength of $570 \mathrm{~nm}$. The amount of formazan dye is in direct proportion to the number of metabolically active cells in the culture. Relative toxicity was calculated as the percentage of surviving cells by setting control cells treated with vehicle as having $100 \%$ surviving cells.

Alkaline single-cell microgel electrophoresis assay. The alkaline single-cell microgel electrophoresis technique (comet assay) was applied to detect DNA strand breaks and alkali labile plus incomplete excision repair sites in single cells.
Slide preparation was performed as previously described by Buehrlen et al (22). The evaluation of the slides was carried out on a DMLB fluorescence microscope (Leica Microsystems, Wetzlar, Germany) with a filter system incorporating a green excitation filter (515-560 $\mathrm{nm}$ band pass), a dichromatic beam splitter (580 nm long pass), and an emission filter (590 nm long pass) at a magnification of $\mathrm{x} 4,003$. For every sample, two slides with 50 randomly selected cells each were counted (total of 100 cells). For analysis of the DNA fragmentation the Comet 5.5 Image System (Kinetic Imaging, Liverpool, UK) was used. For analysis, the olive tail moment (OTM) as a product of the median migration distance and the percentage of DNA in the tail was used (23).

In vitro motility assays. Tumour spheroids were generated by seeding 5,000 cells/well of HLaC78 and FADU cells on ultra-low attachment (ULA) 96-well round-bottomed plates (Corning, Amsterdam, The Netherlands) (24). The surface of the flat-bottomed 96-well plates was coated with $125 \mu \mathrm{g} / \mathrm{ml}$ Matrigel ${ }^{\circledR}$ (Becton-Dickinson, Heidelberg, Germany) for $2 \mathrm{~h}$ at room temperature. Wells were washed twice with phosphate-buffered saline (PBS) and subsequently blocked with $1 \%$ bovine serum albumin in PBS for $1 \mathrm{~h}$. For 3 days on the ULA (see above) plates, pre-cultivated spheroids (see above) of HLaC78 and FADU cell lines were transferred to the coated wells with a multichannel pipette. Spheroids were incubated with or without the Galium decoction $(33.3 \mu \mathrm{l} / \mathrm{ml})$. Migration was recorded by photographing spheroids after 1 and $18 \mathrm{~h}$ with a Leica DMI 4000 inverted fluorescence microscope (Leica Microsystems). Quantification of migrated cells was carried out using ImageJ software [National Institutes of Health (NIH) USA].

Gelatin zymography. Cell lines were treated with $33.3 \mu \mathrm{l} /$ $\mathrm{ml}$ Galium verum extract for $48 \mathrm{~h}$. After $48 \mathrm{~h}$, the cells were seeded after incubation with Galium extract at equal cell numbers in multi-wall plates. Complete medium (MEM or RPMI) was replaced after attachment by Opti-MEM (Invitrogen, Karlsruhe, Germany), which is a complete, serumfree medium. Conditioned medium was collected after $18 \mathrm{~h}$ and concentrated using Amicon ${ }^{\circledR}$ Ultra-4 Centrifugal Filters (Merck Millipore, Darmstadt, Germany). Five microliters of the concentrated medium was subjected to electrophoresis on $10 \%$ SDS-polyacrylamide gels under non reducing conditions (25), containing $1 \mathrm{mg} / \mathrm{ml}$ gelatin (Sigma-Aldrich, Traunstein, Germany). After electrophoresis, gels were renatured two times for $30 \mathrm{~min}$ in $2.5 \%$ Triton $\mathrm{X}-100$ and developed overnight in developing solution $(50 \mathrm{mM}$ Tris- $\mathrm{HCl}$, $\mathrm{pH} 6.8,0.2 \mathrm{M} \mathrm{NaCl}, 10 \mathrm{mM} \mathrm{CaCl}_{2}, 0.02 \% \mathrm{Brij}_{-35)}$ at $37^{\circ} \mathrm{C}$. Subsequently they were stained with Coomassie brilliant blue, destained and dried.

Statistical analysis. All statistical analyses and graphs were performed with GraphPad Prism 4 (Graphpad Software, La Jolla, CA, USA).

\section{Results}

Expression of p-glycoprotein ( $p$-gp; MDR-1). To determine detoxification capacities of HLaC78 and FADU cells, and 


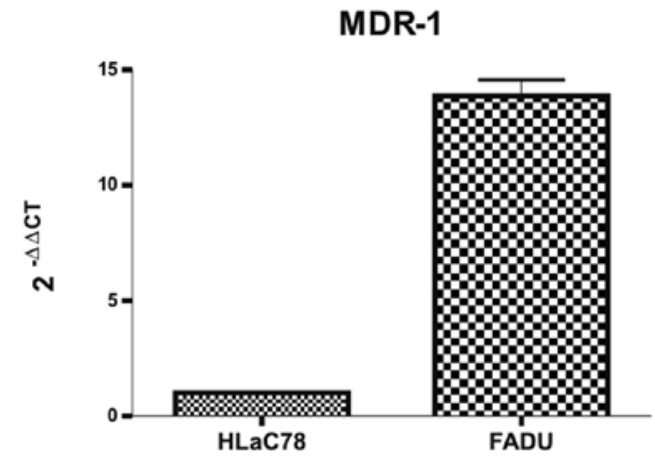

Figure 1. Expression of MDR-1 mRNA, measured by TaqMan qRT-PCR. $y$-axis values were calculated according to the $2^{-\Delta \Delta C T}$ method. Values are mean $\pm \mathrm{SE}$ and were normalized to the expression of GAPDH

mucosal keratinocytes, quantitative RT-PCR was performed. Expression of p-gp in the HLaC78 and FADU cells, and mucosal keratinocytes (MKs) was tested by TaqMan qRT-PCR. qRT-PCR revealed distinctly increased MDR-1 expression in FADU cells, when compared to HLaC78 cells (Fig. 1). There was no amplification detectable in primary MKs.

Cytotoxicity. The two cell lines (FADU and HLaC78) and primary MKs were treated with increasing concentrations of Galium aqueous extract (Fig. 2). Cell viability and cytotoxicity of the used drug were assessed with the MTT assay. Mean percent inhibition was calculated from at least three independent experiments. Galium extract significantly suppressed the growth of both cell lines (Kruskal-Wallis test, $p<0.05$ ). In HLaC78 and FADU cells growth inhibition corresponded to the expression rate of MDR-1 (Fig. 2).

Primary keratinocytes, however, were less affected by high Galium concentrations than HLaC78 cells, although no MDR-1 transcript was detectable in these cells.

There was no obvious correlation between the sensitivity to high Galium concentrations and the proliferation rates of the cell lines/primary cells.

Cell motility on extracellular matrix (ECM) proteins. Investigation of invasion and motility was carried out using spheroid-based experiments. First, these experiments better reflect the solid tumour-microenvironment interaction.
Second, the widely used Boyden chamber assay proved to be not reproducible in the actual system.

Spheroids of both cell lines were grown in ultra-low attachment plates (ULA plates) wells and were subsequently transferred manually to wells coated with Matrigel. Images of the cells were captured after attachment to $\operatorname{ECM}(1 \mathrm{~h}, \mathrm{t}=0)$ and after $18 \mathrm{~h}(\mathrm{t}=18)$.

For quantification of the cells migrating out of the spheroids, the areas of the spheroids at $\mathrm{t}=0$ and $\mathrm{t}=18$ were photographed, and the images were examined using Image $\mathbf{J}$ area calculation. Areas at $\mathrm{t}=0$ were subtracted from the areas measured after 18 h. For each condition (with or without Galium, HLaC78 or FADU cells) at least 10 spheroids were measured.

For evaluation of cell motility, the area at $\mathrm{t}=0$ was set at $100 \%$. The percent of the migrated area was calculated using the following formula:

$$
\% \text { Migrated area }=\frac{100 \times \Delta \text { Area }}{\text { Area }{ }^{\mathrm{t}=0}}
$$

whereas $\Delta$ Area $=$ Area $^{\mathrm{t}=18}$ - Area ${ }^{\mathrm{t}=0}$.

Representative examples for FADU and HLaC78 cells migrating on Matrigel with or without treatment of Galium are shown in Fig. 3.

Comparing the percentage of the migrated areas of $\mathrm{HLaC} 78$ and FADU cells, HLaC78 cells turned out to be highly invasive, compared to the FADU cell line (unpaired t-test, $\mathrm{p}<0.0001$; Fig. 4).

In both cell lines, Matrigel invasion was inhibited significantly by Galium ( $<0.0001$; Fig. 5) decoction at sublethal doses of $33.3 \mu \mathrm{l} / \mathrm{ml}$ (unpaired t-test, $\mathrm{p}<0.0001$ ). Comparison of the percent reduction of the migrated areas caused by Galium in the two cell lines revealed a stronger invasion inhibition in the aggressively invading $\mathrm{HLaC} 78$ cells $(5104 \pm 287.3 \%)$ when compared to FADU cells $(723.3 \pm 48.79 \%)$.

Expression of matrix metalloproteinase MMP-2 and MMP-9 and their inhibitors. FADU and $\mathrm{HLaC} 78$ cell lines were cultivated with or without Galium extract for 4 or 8 h, respectively. Expression levels of MMP-2 and MMP-9 as well as TIMP-1 and TIMP-2 RNA were measured using qRT-PCR. Results are displayed in Fig. 6.

In both cell lines, MMP-9 and TIMP-1 were significantly upregulated after a 4-h incubation with Galium decoction.
FADU

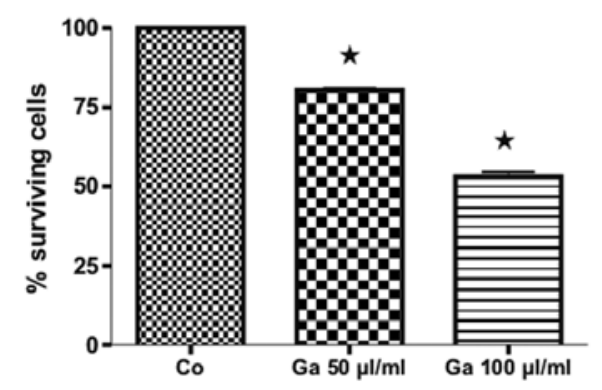

HLaC78

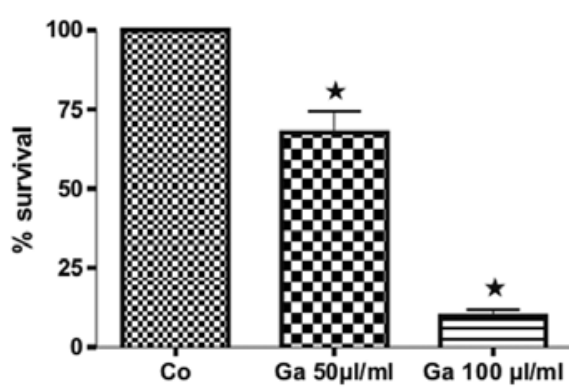

MK

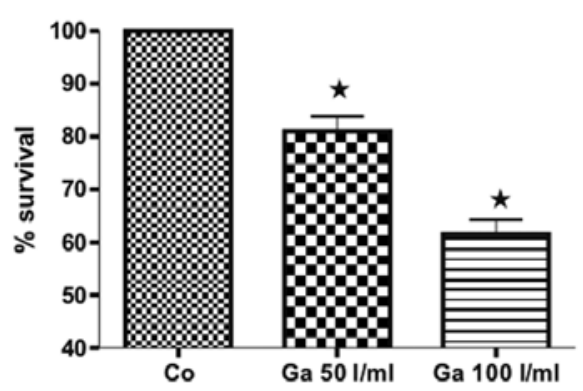

Figure 2. Cytotoxicity of Galium decoction on FADU and HLaC78 cell lines, determined using the MTT assay. "p<0.0001, statistically significant values; one-way analysis of variance. Co, control; Ga, Galium decoction; MKs, mucosal keratinocytes. 


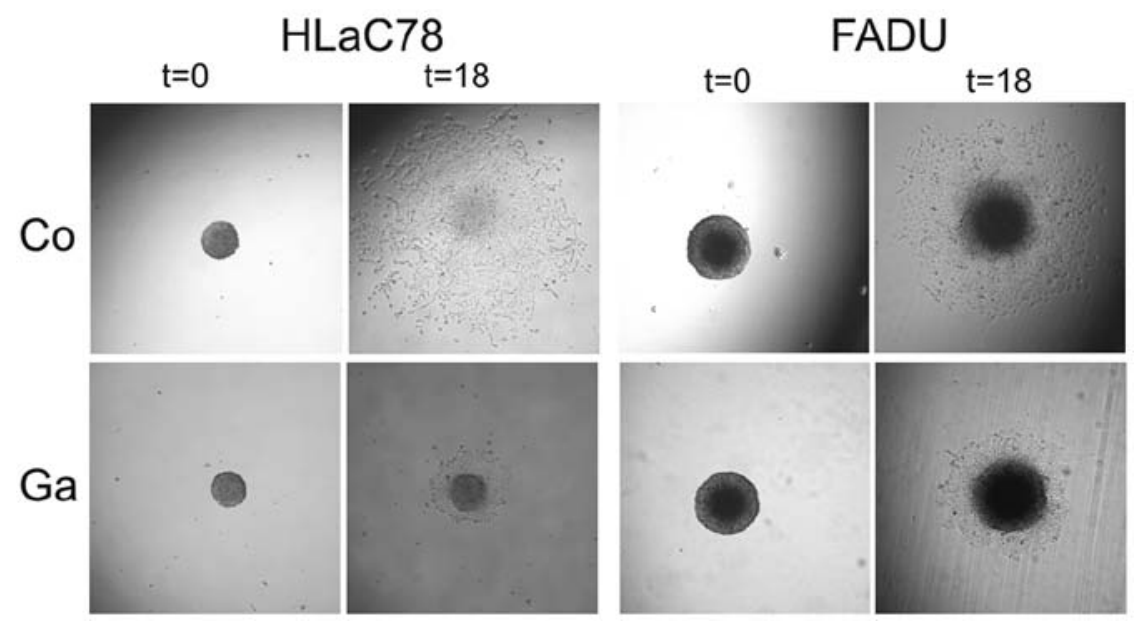

Figure 3. Invasion patterns of HLaC78 and FADU cells on Matrigel-coated surfaces at $\mathrm{t}=0$ ( $0 \mathrm{~h}$ after transfer to substrate) and $\mathrm{t}=18$ (18 $\mathrm{h}$ later) with Galium $\operatorname{verum}(\mathrm{Ga})$ aqueous extract or without [control $(\mathrm{Co})]$.

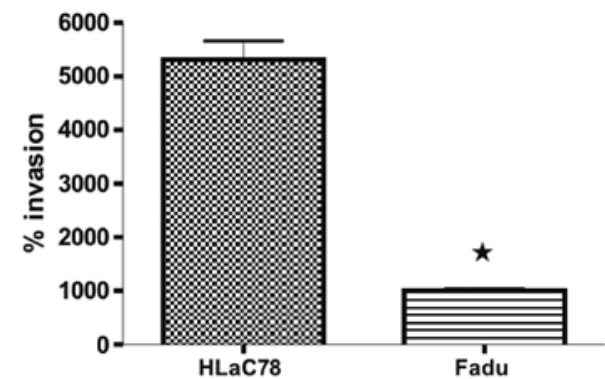

Figure 4. Percentage of invasion of HLaC78 or FADU cells on Matrigel. " $\mathrm{p}<0.0001$, statistically significant value; unpaired t-test.

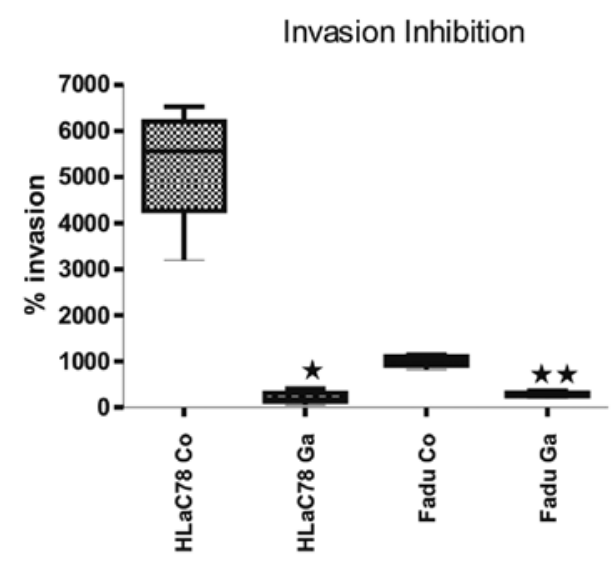

Figure 5. Percentage of inhibition of Matrigel invasion by Galium aqueous extract. "p $<0.0001$ and ${ }^{* *} \mathrm{p}<0.05$, statistically significant values; unpaired t-test. Co, control; Ga, Galium decoction.

After $8 \mathrm{~h}$ however only TIMP-1 expression remained increased in FADU cells, when compared to untreated controls. HLaC78 cells displayed no significant changes in gelatinase A and $\mathrm{B}$ and TIMP mRNA expression after $8 \mathrm{~h}$.

MMP-2/-9 activity. To test the actual proteolytic activities, conditioned media of $\mathrm{HLaC} 78$ and FADU cells incubated with or without Galium aqueous extract for $18 \mathrm{~h}$ were applied to gelatin zymographic gels.

FADU cells showed higher overall gelatinolytic activity than HLaC78 cells. Gelatin zymography revealed no significant changes in MMP-2/-9 activity after treatment with Galium decoction in the HLaC78 cell line. Galium-treated FADU cells showed even higher MMP-9 and MMP-2 activity, when compared with the untreated control cells (Fig. 7).

DNA protection. The Olive Tail Moment (OTM) was used to evaluate DNA damage. Benzo[ $a]$ pyrene, found in tobacco smoke (including cigarette smoke), has been shown to cause genetic damage in lung cells that was identical to the damage observed in the DNA of most malignant lung tumours (25). After a 1-h treatment of MKs with $200 \mathrm{mM}$ benzo[a]pyrene, a significant increase in the mean olive tail moment was observed (Fig. 8). An overnight preincubation with Galium decoction $(50 \mu \mathrm{l} / \mathrm{ml})$ significantly decreased benzo[ $a]$ pyrene-induced DNA damage (Fig. 8).

\section{Discussion}

Galium verum is a traditional medicinal plant commonly used for the exogenous cure of psoriasis, delayed wound healing or as a tea with diuretic effect for the cure of pyelitis or cystitis (3).

Some popular compendia for herbal medicine recommend Galium verum for the therapy of mouth/neck cancer $(27,28)$. According to detailed survey by Hartwell (15), Galium verum was traditionally used in Europe and Northern America for the treatment of cancerous ulcers or breast cancer.

In the present study the effect of a simple decoction of Herba galii lutei on two different head and neck cancer cell lines, differing in cell motility and chemoresistance were tested, and significant growth inhibition was noted at higher doses in both cell lines, albeit somewhat extenuated in the stronger MDR-1-expressing FADU cells. On sensible primary mucosal cells, showing no p-glycoprotein expression, however, Galium decoction proved to be less toxic than in the HLaC78 laryngeal cancer cell line. 
FADU 4h

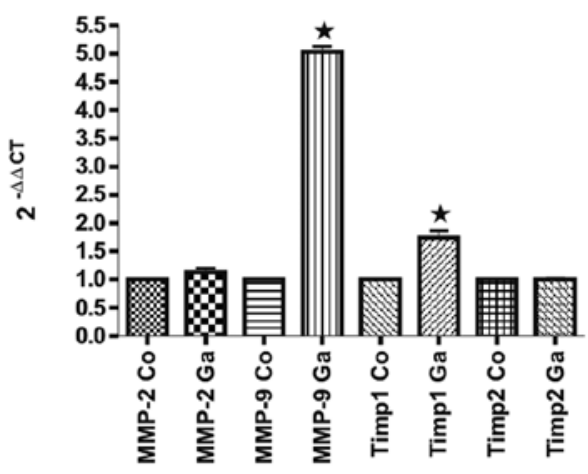

HLaC78 4h

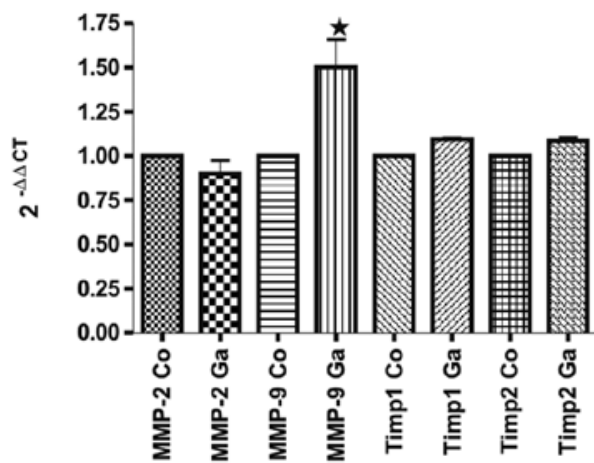

FADU $8 \mathrm{~h}$

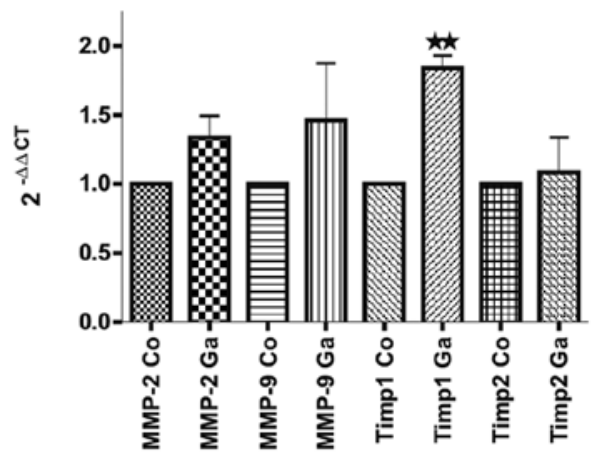

HLaC78 8h

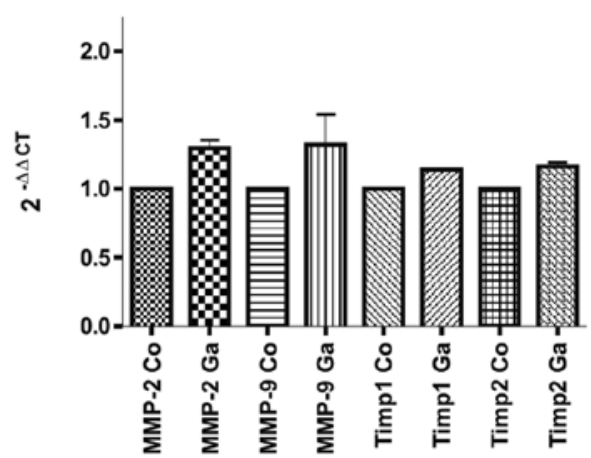

Figure 6. Gene expression of gelatinolytic matrix-metalloproteinases MMP-2 and MMP-9 and their inhibitors TIMP-1 and TIMP-2. ${ }^{*}$ p $<0.0001$ and ${ }^{* *} \mathrm{p}<0.05$, statistically significant values; unpaired t-test. Co, control; Ga, Galium decoction.

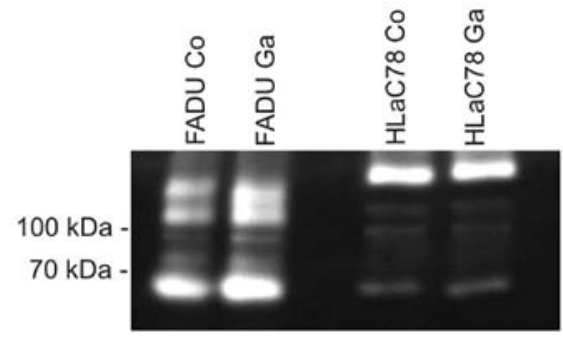

Figure 7. Analysis of gelatinolytic activity using gelatin-zymography. Molecular weight in kilo dalton (kDa) is indicated. Co, control; $\mathrm{Ga}$, Galium decoction.

In general, high motility of tumour cells is frequently correlated with increased chemoresistance, as previously shown for the paclitaxel-resistant head and neck cancer cell line Hep2-Tax (20). In HLaC78 cells, high cellular motility is combined with a slow division rate and chemosensitivity. Increased motility of cancer cells has been reported to be based on higher expression rates of a variety of adhesion and motility associated and proteolytic genes as well as transcription factors (reviewed in ref. 29). In the present study we did not observe striking effects of Galium decoction on mRNA expression of the matrix metalloproteinases MMP-9 and MMP-2 or their inhibitors. Gelatinolytic activity also remained unaffected by preincubation with Galium verum decoction in both cell lines.

Potential main agents in Galium extracts, used for the present and previous study are chlorogenic acid, Luteolin-

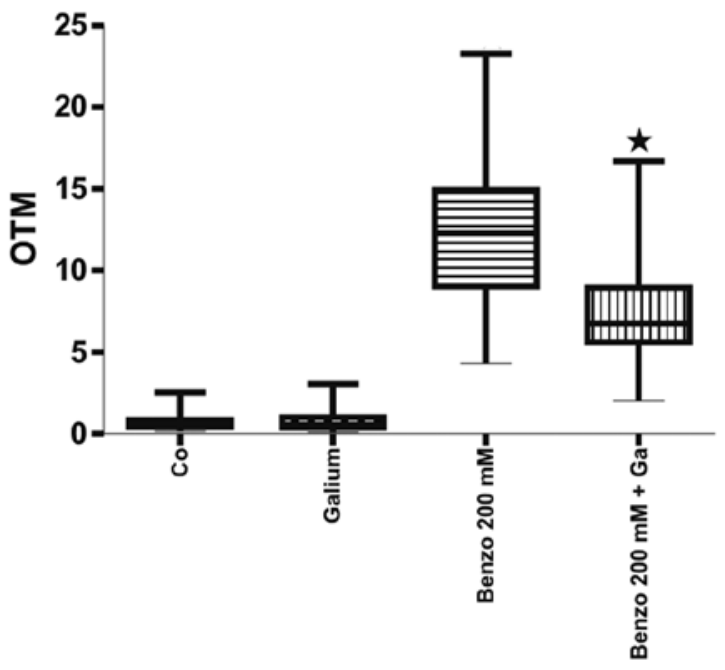

Figure 8. DNA fragmentation expressed by the olive tail moment (OTM) in human mucosal keratinocytes after exposure to benzo[a]pyrene with or without preexposure to aqueous Galium verum (Ga) extract. "p $<0.0001$, statistically significant value; unpaired t-test. Co, control.

7-O-glucoside and rutoside (20). Chlorogenic acid has been shown to be antimetastatic in vivo and in vitro in a variety of tumour systems (30-32). The antimetastatic activity appeared in combination with the downregulation of MMP-9 expression/activity (31-33). In the present study, gelatinolytic activity was not affected by non-toxic Galium doses, indicating that 
motility inhibition by Galium extract is not necessarily caused by chlorogenic acid (alone). HLaC78 spheroids formed very tight, nearly indestructible spheroids. Video recordings (data not shown) revealed that $\mathrm{HLaC78}$ spheroids incubated with Galium decoction needed more time to adhere to the Matrigelcoated surface than the untreated spheroids. It seems likely that the strong motility inhibition in HLaC78 cells is based on changes in cell attachment and/or tight cell-cell contacts in the close tissue-like formations.

In the second approach, it was demonstrated that primary epithelial cells of the upper aerodigestive tract are protected against genotoxic agents by an aqueous extract of Galium verum. Antioxidative properties of Galium verum extract have been described previously (11), suggesting DNA-protective properties of the extract as well.

In summary, Galium verum aqueous extract revealed a growth inhibitory effect on the cell lines HLaC78 and FADU, as well as on primary mucosal keratinocytes at high doses. The toxic effect appears to be modulated by detoxification capacities of the carcinoma cell lines, since the MDR-1-expressing FADU cells were less sensitive to higher Galium doses. In primary mucosal cells, void of p-glycoprotein expression, however, Galium extract also exerted only low toxicity even at high concentrations. At non-toxic concentrations, Galium aqueous extract inhibited dispersion of HLaC78 and FADU spheroidal cells on Matrigel-coated surfaces significantly, even more pronounced in the highly motile cell line HLaC78. The observed inhibition of motility was not caused by reduced expression or activity of matrix-metalloproteinases.

Galium decoction protected DNA of primary mucosal epithelial cells against the mutagenic action of benzo $[a]$ pyrene, one of the major DNA-damaging agents in cigarette smoke. Galium verum aqueous extract, therefore, may be useful as an effective and safe concomitant therapeutic approach in accessible tumours of the mouth or upper aerodigestive tract.

\section{Acknowledgements}

We would like to thank Dr Ivo Pischel (PhytoLab GmbH \& Co. KG) for supplying the Herba gallii lutei. We further thank Dr Johannes Gottfried Mayer and Dr Heike Will (University of Wuerzburg, Forschergruppe Klostermedizin) for providing historical data and for the stimulating discussion.

\section{References}

1. Guntinas-Lichius O, Wendt T, Buentzel J, et al: Head and neck cancer in Germany: a site-specific analysis of survival of the Thuringian cancer registration database. J Cancer Res Clin Oncol 136: 55-63, 2010.

2. Pfreundner L, Hoppe F, Willner J, Preisler V, Bratengeier K, Hagen R, Helms J and Flentje M: Induction chemotherapy with paclitaxel and cisplatin and CT-based 3D radiotherapy in patients with advanced laryngeal and hypopharyngeal carcinomas - a possibility for organ preservation. Radiother Oncol 68: 163-170, 2003.

3. Blaschek W, Ebel S, Hilgenfeldt U, Holzgrabe U, Reichling J and Schulz V: Hagers Enzyklopädie der Arzneistoffe und Drogen (Hager ROM; elektronische Buch-Version). Springer Verlag, Berlin, 2009 (In German).

4. Böjthe-Horváth K, Hetényi F, Kocsis Á, Szabó L, Varga-Balázs M, Máthé I Jr and Tétényi P: Iridoid glycosides from Galium verum. Phytochemistry 21: 2917-2919, 1980.
5. Zhao C, Shao J, Cao D, Zhang Y and Li X: Chemical constituents of Galium verum. Zhongguo Zhong Yao Za Zhi 34: 2761-2764, 2009 (In Chinese).

6. Corrigan D, Timoney RF and Donnelly D: Iridoids and alkanes in twelve species of Galium and Asperula. Phytochemistry 17: 1131-1133, 1978

7. Shafaghat A, Salimi F, Aslaniyan N and Shoaei Z: Flavonoids and an ester derivative isolated from Galium verum L. World Appl Sci J 11: 473-477, 2010.

8. Zhao CC, Shao JH, Li X, Kang XD, Zhang YW, Meng DL and Li N: Flavonoids from Galium verum L. J Asian Nat Prod Res 10: 613-617, 2008

9. Zhao CC, Shao JH, Li X, Xu J and Wang JH: A new anthraquinone from Galium verum L. Nat Prod Res 20: 981-984, 2006.

10. Borisov MI, Zaitsev KV and Zaitsev VG: The chemical composition of Galium verum. Chem Nat Compd 7: 511, 1971.

11. Mavi A, TerziZ, Ozgen U, Yildirim A and Coşkun M: Antioxidant properties of some medicinal plants: Prangos ferulacea (Apiaceae), Sedum sempervivoides (Crassulaceae), Malva neglecta (Malvaceae), Cruciata taurica (Rubiaceae), Rosa pimpinellifolia (Rosaceae), Galium verum subsp. verum (Rubiaceae), Urtica dioica (Urticaceae). Biol Pharm Bull 27: 702-705, 2004.

12. Khaliq Jan A1, Raza Shah M, Anis I and Khan Marwat I: In vitro antifungal and antibacterial activities of extracts of Galium tricornutum subsp. longipedunculatum. J Enzyme Inhib Med Chem 24: 192-196, 2009.

13. Morimoto M, Tanimoto K, Sakatani A and Komai K: Antifeedant activity of an anthraquinone aldehyde in Galium aparine $\mathrm{L}$. against Spodoptera litura F. Phytochemistry 60: 163-166, 2002.

14. Tzakou O, Mylonas P, Vagias C and Petrakis PV: Iridoid glucosides with insecticidal activity from Galium melanantherum. Z Naturforsch C 62: 597-602, 2007.

15. Hartwell JL: Plants Used Against Cancer: A Survey. Quarterman Publications, Lawrence, MA, pp438-439, 1982.

16. Amirghofran Z, Bahmani M, Azadmehr A and Javidnia K: Anticancer effects of various Iranian native medicinal plants on human tumor cell lines. Neoplasma 53: 428-433, 2006.

17. Zhao R, Chen Z, Jia G, Li J, Cai Y and Shao X: Protective effects of diosmetin extracted from Galium verum $\mathrm{L}$. on the thymus of U14-bearing mice. Can J Physiol Pharmacol 89: 665-673, 2011.

18. Zenner HP, Lehner W and Herrmann IF: Establishment of carcinoma cell lines from larynx and submandibular gland. Arch Otorhinolaryngol 225: 269-277, 1979.

19. Imaizumi F, Asahina I, Moriyama T, Ishii M and Omura K: Cultured mucosal cell sheet with a double layer of keratinocytes and fibroblasts on a collagen membrane. Tissue Eng 10: 657-664, 2004.

20. Schmidt M, Scholz CJ, Gavril GL, et al: Effect of Galium verum aqueous extract on growth, motility and gene expression in drug-sensitive and -resistant laryngeal carcinoma cell lines. Int J Oncol 44: 745-760, 2014.

21. Livak KJ and Schmittgen TD: Analysis of relative gene expression data using real-time quantitative PCR and the $2^{-\Delta \Delta C_{\mathrm{T}}}$ method. Methods 25: 402-408, 2001.

22. Buehrlen 1,Harréus UA, Gamarra F, Hagen R and Kleinsasser NH: Cumulative genotoxic and apoptotic effects of xenobiotics in a mini organ culture model of human nasal mucosa as detected by the alkaline single cell microgel electrophoresis assay and the annexin V-affinity assay. Toxicol Lett 169: 152-161, 2007.

23. Olive PL and Banáth JP: Growth fraction measured using the comet assay. Cell Prolif 25: 447-457, 1992.

24. Vinci M, Gowan S, Boxall F, et al: Advances in establishment and analysis of three-dimensional tumor spheroid-based functional assays for target validation and drug evaluation. BMC Biol 10: 29, 2012.

25. Heussen C and Dowdle EB: Electrophoretic analysis of plasminogen activators in polyacrylamide gels containing sodium dodecyl sulfate and copolymerized substrates. Anal Biochem 102: 196-202, 1980.

26. Denissenko MF, Pao A, Tang M and Pfeifer GP: Preferential formation of benzo $[a]$ pyrene adducts at lung cancer mutational hotspots in P53. Science 274: 430-432, 1996.

27. Willfort R: Gesundheit Durch Heilkräuter. Trauner Verlag, 1982 (In German).

28. Treben M: Gesundheit Aus Der Apotheke Gottes. Ennsthaler Verlag, Steyr, 1980 (In German).

29. Sahai E: Mechanisms of cancer cell invasion. Curr Opin Genet Dev 15: 87-96, 2005. 
30. Yagasaki K, Miura Y, Okauchi R and Furuse T: Inhibitory effects of chlorogenic acid and its related compounds on the invasion of hepatoma cells in culture. Cytotechnology 33: 229-235, 2000.

31. Hwang YP, Yun HJ, Choi JH, et al: 3-Caffeoyl, 4-dihydrocaffeoylquinic acid from Salicornia herbacea inhibits tumor cell invasion by regulating protein kinase $C-\delta$-dependent matrix metalloproteinase-9 expression. Toxicol Lett 198: 200-209, 2010 .
32. Tsai CM, Yen GC, Sun FM, Yang SF and Weng CJ: Assessment of the anti-invasion potential and mechanism of select cinnamic acid derivatives on human lung adenocarcinoma cells. Mol Pharm 10: 1890-1900, 2013.

33. Jin UH, Lee JY, Kang SK, et al: A phenolic compound, 5-caffeoylquinic acid (chlorogenic acid), is a new type and strong matrix metalloproteinase-9 inhibitor: isolation and identification from methanol extract of Euonymus alatus. Life Sci 77: 2760-2769, 2005. 